\title{
大容量通信を実現する, 宇宙光通信の研究開発動向
}

\section{Research and Development Trends of Space Optical Communications for Realizing Large Capacity Communication}

荒木智宏 Tomohiro Araki ${ }^{\dagger}$

\begin{abstract}
長い助走期間を終えて，宇宙での光通信はようやく実用段階に到達した．本論文では，まず宇宙光通信の れい明期からの歴史について概説する. 次に，世界の宇宙光通信の研究開発動向について距離別に分類し 述べる．更に，宇宙光通信を実現するための技術及び課題を，主に大容量通信技術の観点から紹介する．その中で，特に送受 信技術については， loT 時代を支える大容量通信技術である光ファイバ通信システム・デバイス技術の成果を活用していること を，国際標準化の動向とともに紹介する.
\end{abstract}

Key Words＼cjkstart宇宙，光通信，通信方式，大容量通信

\section{宇宙光通信とは}

読者の皆さんは，「光通信」と聞いて何を思い浮 かべるだろうか. 本誌の読者であれば，まず間違い なく光ファイバを用いた有線の光ファイバ通信を思 い浮かべることであろう。しかし，本論文で取り上 げるのは宇宙での衛星と衛星の間，若しくは衛星と 光地上局（電波のアンテナの代わりに，光学望遠鏡 =光アンテナを備える, 衛星と光通信を行うための 施設）の間の，無線の光通信についてである.

地上の光ファイバ通信技術では，10 年ごとにほ ぼ 2 桁の大容量化が実現された。現在では一人一 人がスマートフォンで数十 Mbit/s のデータ伝送速 度を日常的に扱い，動画像ストリーミングや SNS を楽しんでいるが，これらを実現するのは基地局間 を結ぶ大容量光ファイバ網である。一方，人類の宇 宙活動でも，例えば地球観測衛星の観測センサの分 解能向上，観測領域の拡大に伴い，伝送すべきデー 夕量は増大し続けており，地上同様に大容量通信が 望まれている。また，民間の商用通信衛星において も, very High Throughput Satellite (vHTS) と呼 ばれる, 衛星 1 機で数百 Gbit/s，将来的には 1Tbit/s を超える通信容量を持つ衛星が登場しつつ あり，衛星一ゲートウェイ局（衛星基地局）間の通 信に光通信の活用の検討が始まっている ${ }^{(1)}$. 衛星 間や衛星一地上間の無線の光通信である宇宙光通信

†宇宙航空研究開発機構筑波宇宙センター, つくば市 Japan Aerospace Exploration Agency Tsukuba Space Center, Tsukuba-shi, 300-8505 Japan
は，今後の宇宙デー夕伝送システムにおいて以下の 理由で飛躍的な大容量通信の実現と, 軽量小形化・ 低消費電力化を可能とするものと期待されている ${ }^{(2)}$.

D 電波に比べてほぼ4桁高周波带域であり, 例えば波長 1530-1570 nm 帯ではほぼ5 THz（191.0〜 195.9THz）の帯域が使用可 能である。

D 電波帯域と異なり，周波数干渉に伴う使用周 波数や帯域幅等の制約が今のところ存在しな い.

D 送信ビームの集光性（直進性）が高く，秘 匿性に優れる。この特徵は高い指向精度が必 要になることも意味する。

○ アンテナ径を小さくできるために軽量小形化 が期待できる。

本論文の構成は次のとおりである.2.では，宇 宙光通信の特徴とこれまでの歴史を概説する. 3. で は，宇宙光通信を距離別に分類し，世界の最新研究 開発動向を述べる.4.では，主に大容量通信技術 に焦点を当てた技術動向と課題の紹介を行う. 5. は 本論文のまとめである。

\section{宇宙光通信の特徵と歴史}

21 世紀の最初の 10 年までは，前章で述べた高い 集光性に伴う高精度指向の実現が技術的な課題で あった。必要な精度を電波 (RF : Radio Frequency) 通信と比較してみよう。例えばJAXA の地球観測衛 星「だいち 2 号」に搭載された, $\mathrm{Ka}$ バンド $(26 \mathrm{GHz}$ 
帯）を用いた衛星間通信用アンテナ ${ }^{(3)}$ は直径 $77 \mathrm{~cm}$ のアンテナをステッピングモータを用いて駆動系と し, 指向精度 0.29deg（5mrad）を達成しており， 自機と当時のデータ中継衛星「こだま」の軌道情報 を基にしたオープンループでの指向制御で，「だい ち2号」一「こだま」間の衛星間通信が可能であっ た。一方, 光通信は, 光アンテナ径 $10 \mathrm{~cm}$ と使用 波長 $1.55 \mu \mathrm{m}$ を想定すると, ビーム広がり（半値 半幅）は $10 \mu \mathrm{rad}$ となり, 電波の $5 \mathrm{mrad}$ と比べて ほぼ 4 桁高い $1 \mu \mathrm{rad}$ (約 $0.00006 \mathrm{deg}$ ) オーダの指 向制御精度が必要となる。大雑把にこれをたとえる と, 富士山頂にあるサッカーボールを， $100 \mathrm{~km}$ 離 れた東京スカイツリーから狙うことになる（図 1). 有名な劇画の主人公, 世界一のスナイパーの「ゴル ゴ 13」も真っ青になるであろう高精度であり，送 信側からの一方的なオープンループ指向制御ではこ の精度の実現は困難である。そのため、通信相手か らのレーザを受信し，その方向にレーザを送り返し て回線を確立・維持する「捕捉追尾」技術が，電波 とは比べ物にならないほど重要になる。

ここから宇宙光通信の歴史を紹介する．宇宙光通 信の研究は, 欧米では 1970 年代より行われてい

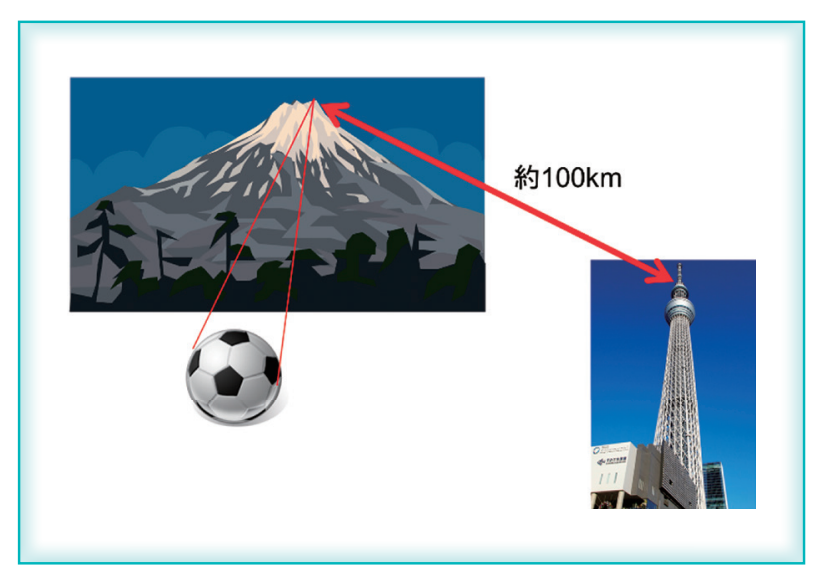

図 1 宇宙光通信における指向精度のたとえ

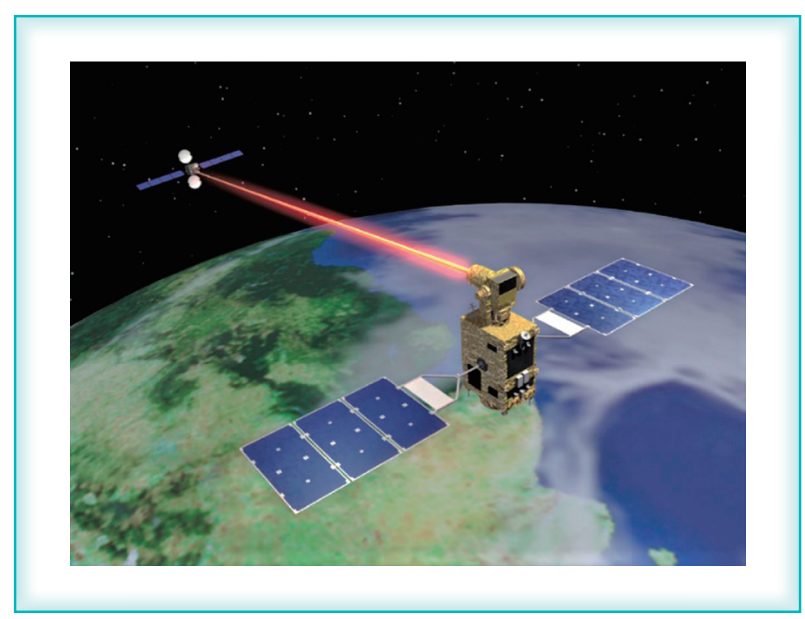

図 2 「きらり」軌道上実験想像図
た (2),(4). 今となってはいささか信じ難いことに, 当時は炭酸ガスレーザの使用が考えられていた。我 が国においては, 研究の開始については遅れを取っ たが，実際に衛星に搭載しての軌道上実験は世界に 先んじている。郵政省通信総合研究所（当時, 現 NICT ・情報通信研究機構) が開発し, 宇宙開発事 業団（当時，現 JAXA）が開発した「きく6 号」 (ETS-6:Engineering Test Satellite 6) に搭載され たレーザ通信装置 (LCE:Laser Communication Equipment）による，衛星一地上間光通信の実現 （1994 年）が，世界初の宇宙光通信であった ${ }^{(5)}$.

欧州宇宙機関 (ESA:European Space Agency) は, 1990 年代に光衛星間通信システムの開発を進 め, フランスの地球観測衛星 SPOT-4（1997 年打 上げ）と，ESAの静止通信実験衛星 ARTEMIS (2001 年打上げ) との間での衛星間光通信に世界で 初めて成功した ${ }^{(4)}$.また, SPOT-4 から ARTEMIS への衛星間光通信を用いた光データ中継による実 デー夕伝送も行われた。加えて, JAXAが 2005 年 に打ち上げた光衛星間通信実験衛星「きらり」 (OICETS:Optical Inter-orbit Communications Engineering Test Satellite) と ARTEMIS の間で, 異なる機関間での世界初の衛星間光通信，及び双方 向通信に成功した ${ }^{(6)}$. なお「きらり」は, NICT と の協力の下に, 世界初の低軌道 (LEO:Low earth orbit）衛星一地上間の光通信実験にも成功してい る。「きらり」の軌道上実験のイメージ図を図 2 に, 「きらり」の光通信装置の外観を図 3 に示す.

以上の実験は，送信側に波長 $0.8 \mu \mathrm{m}$ 帯のひ化ガ リウム・アルミニウム (GaAlAs:Gallium-Aluminum Arsenide) 一レーザダイオード (LD:Laser Diode), 受信側にアバランシフォトダイオード

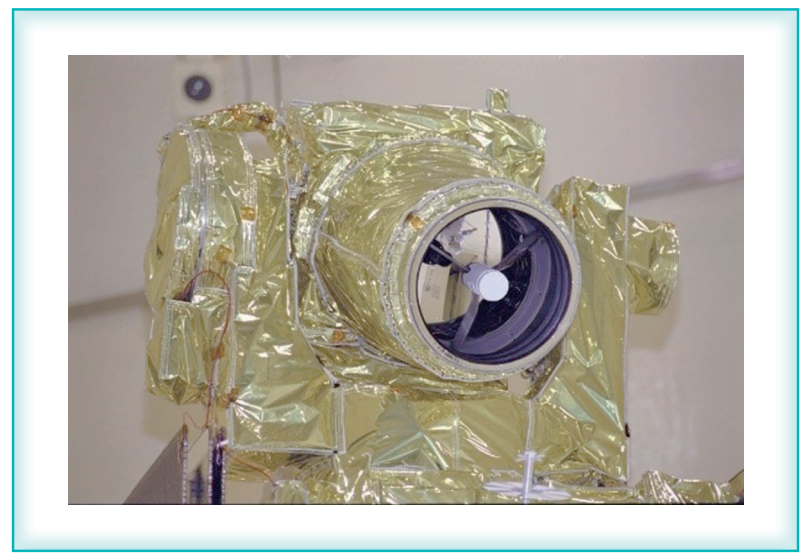

図 3 「きらり」の光通信装置の外観 光アンテナ径 $26 \mathrm{~cm}$, 熱ひずみによる変形を防ぐため, 鏡 面に加え鏡筒とトラスも全て低膨張ガラスで構成された構 造となっている. 
(APD:Avalanche Photo-Diode) を用いた，強度 変調 ・直接検出 (IM/DD:Intensity Modulation, Direct Detection）によるものである。通信速度は 「きらり」から ARTEMIS への伝送レートで, 50Mbit/s（ARTEMIS から「きらり」への伝送レー トが $2 \mathrm{Mbit} / \mathrm{s}$ ）にすぎず，前述の高精度な捕捉追尾 を達成し宇宙光通信が実現可能であることを立証す るためのミッションであった。なお，このとき「き らり」で使用された LD は, 定格出力 $300 \mathrm{~mW}$ (CW, 単一モード) の GaAlAs-LD で，「きらり」開 発スタート時の 1994 年時点では世界最高出力のも のであった。

現在この出力の単一モード LD は, CD/DVD 書 込久用 LD として, 安価かつ幅広く使用されている。 波長 $0.8 \mu \mathrm{m}$ 帯を用いた宇宙光通信は，3. 以降に述 べるように現在から将来の大容量通信衛星に用いら れてはおらず，いわば宇宙光通信のれい明期を支え た技術と言える。ただし, 最近になって情報セキュ リテイの観点から強い関心を集めている, 衛星を用

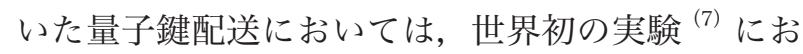
いて用いられており, 用途を変えて使い続けられて いる.

本章の最後に, 図 2 にまつわる小話を紹介する。 光アンテナ（望遠鏡）からレーザを送信しているこ の図はインパクトがあるのか,「ゴルゴ 13」にこの 図を参考にしたとしか思えない絵が出てきたエピ ソードがある ${ }^{(8)}$. 残念ながら，宇宙光通信の実験 衛星としてではなく, 別目的の衛星としてであっ た。当時の筆者の周りは，「『きらり』が『ゴルゴ 13』に載ったぞ!もっとも，○○衛星としてだけ
ど」と微苦笑をしていたものである.

\section{宇宙光通信の分類ごとの動向}

\section{1 宇宙光通信の分類}

本論文では，宇宙光通信をその通信距離によって 3 種類に分類する．図 4 にその概要を示す.

まず，(1)地球からの距離がおよそ 38 万 $\mathrm{km}$ 上で ある月や, 惑星 (火星で 0.4 億 $\mathrm{km}$ から 2 億 $\mathrm{km}$ ) との, 超長距離通信である. 次に, (2)地球の赤道 上，およそ地表から距離 $36,000 \mathrm{~km}$ の静止軌道 (GEO:Geostationaly Earth Orbit) 上の静止衛星 を中心とする宇宙光通信である。中軌道と呼ばれる 高度 $20,000 \mathrm{~km}$ 程度の軌道上の衛星を使用する通 信もここに含める。最後に，(3)おおむ称地表から高 度 $400 \mathrm{~km} \sim 1,000 \mathrm{~km}$ を周回する低軌道 (LEO:Low earth orbit）衛星が主体となる，LEO 衛星間，及 び LEO 衛星一地上間の距離が 1,000〜2,000km の 宇宙光通信である。国際宇宙ステーション (ISS:International Space Station) も高度 約 $400 \mathrm{~km}$ の低軌道上を周回しており、ここに分類さ れる。

\section{2 月・惑星との光通信}

まず，月惑星との光通信について簡単に紹介す る. 地球近傍における光通信においては日欧に先行 を許した，米国航空宇宙局 (NASA:National Aeronautics and Space Administration) であっ たが, 月探査機からの光通信は 2013 年に打ち上げ た月探査機 LADEE と光地上局との間で，世界で初

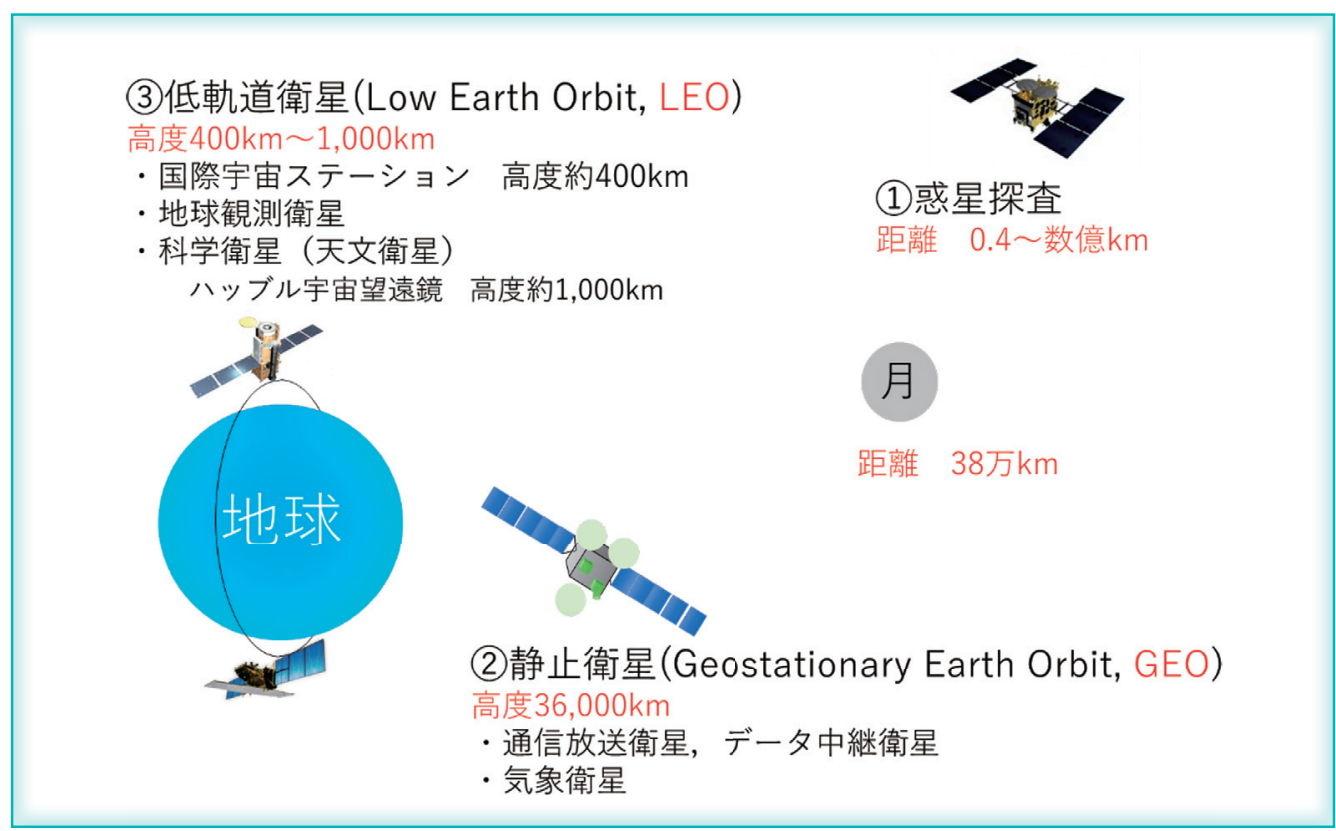

図 4 宇宙光通信の分類 
めて成功している ${ }^{(9)}$. 光地上局は米国内 2 か所及 び ESAのカナリア諸島テネリフェ山頂の光地上局 の, 計 3 か所との光通信に成功している.

現在，この実績を基に，NASA ジェット推進研 究所 (JPL:Jet Propulsion Laboratory) を中心と して小惑星探査機 Psyche との, 惑星間距離での光 通信実験が計画中である ${ }^{(10)}$.

\section{3 静止衛星を用いた光通信}

ARTEMIS，及び「きらり」の成功を受け，宇宙 光通信は, LEO 地球観測衛星のデー夕を静止衛星 で中継する, 光デー夕中継の分野から高速化と実用 化の時代に移った。

ここでデータ中継について簡単にまとめる。低軌 道衛星が, 日本の地上局（例えば JAXA 勝浦局） と通信できる範囲は，図 5 の明るい範囲のみであ り，低軌道衛星がこの範囲を通過する 1 日に 4 回 程度, 1 回当り 10 分前後しか通信を行うことがで きない. 一方, 静止軌道からは常に地球のほぼ半分

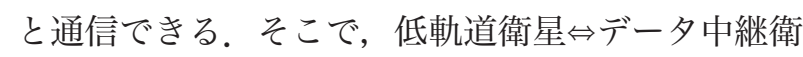
星↔地上局とデータ中継衛星を介して通信を行うこ とで, 低軌道衛星と地上局間で長時間の通信を行う ことが，データ中継である，JAXAが打ち上げて運 用していたデー夕中継衛星「こだま」が低軌道衛星 と通信可能な範囲を図 6 に示す，なお，低軌道衛 星↔デー夕衛星の回線を衛星間回線, デー夕衛星 $\Leftrightarrow$ 地上局の回線をフィーダリンクと呼ぶことが多い.

静止軌道に複数機の中継衛星を配置すれば，常に 低軌道衛星と通信を行うことができる。米国は，ス ペースシャトルや国際宇宙ステーションと 24 時間 切れることのない通信回線の確保のため. 1983 年 から Tracking and Data Relay Satellite (TDRS) を延べ 12 機打ち上げ, 10 機が運用中である ${ }^{(11)}$. JAXA の宇宙飛行士が ISS に搭乗した際にテレビ中 継を行うことがあるが,これは全てNASAの TDRS 経由で行われている.

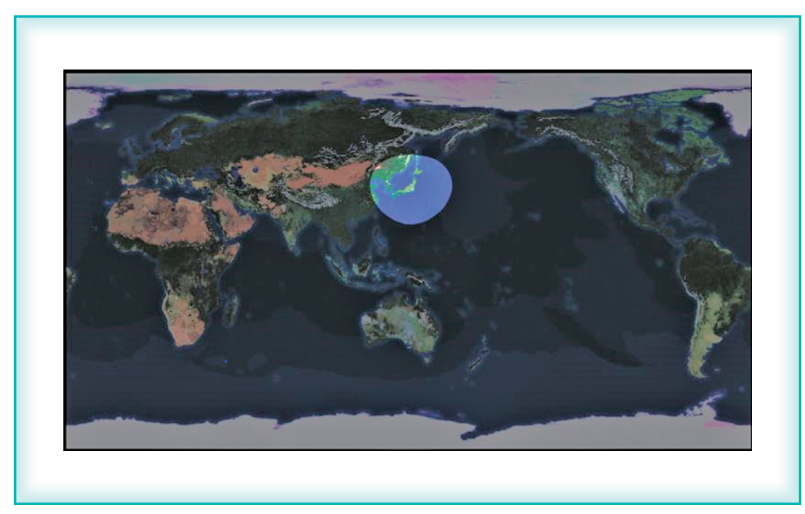

図 5 低軌道衛星が勝浦局と通信可能な範囲
電波による通信と比較して, 宇宙光通信において 特徵的なのは, 宇宙通信全体から見ればニッチな分 野と言ってよい実用化が衛星間回線から始まったこ とである。これは, 光通信の弱点として, 大気の摇 らぎや水蒸気に弱く, 特に雲や霧があると遮断され てしまうことに起因する。つまり，大気のない宇宙 空間での通信である衛星間通信に光通信を割り当 て, 電波は衛星一地上間回線（フィーダリンク）に 専ら割り当てることで, 限られた電波資源を有効利 用するという考え方によっている.

ESA は，独航空宇宙センター (DLR:Das Deutsche Zentrum fur Luft- und Raumfahrt) が 開発した技術を用いて欧州データ中継システム (EDRS:European Data Relay System) を運用・ 開発中であり，従来の電波による通信では困難な超 高速通信を可能とする光通信技術を実用化してい

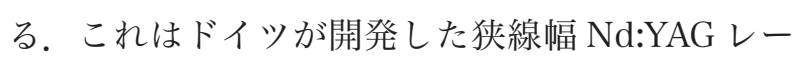
ザを用いた， 2 位相シフトキーイング (BIT/ SK:Binary Phase-Shift Keying) 変調と, ホモダイ ン検波による復調技術により, ユーザデー夕伝送 レート $1.8 \mathrm{Gbit} / \mathrm{s}$ ，変復調レート $2.8 \mathrm{Gbit} / \mathrm{s}$ を実現 している. EDRS から地上までは波長と偏波で 4 多 重化した Ka バンド回線で伝送される. EDRSでは, ALPHASAT 衛星（2013 年）での軌道上実証を完 了し，静止のデータ中継である EDRS-A（2016 年), EDRS-C (2019 年打上げ予定) と, ESAの地 球観測衛星である SENTINEL 衛星シリーズとの間 で, 光データ中継の実運用を開始している ${ }^{(12)}$. な お EDRS 計画は, ESA と AIRBUS 社が費用を折半 する官民共同プロジェクトとして推進されている。 EDRS-A，C は大西洋上の静止衛星であるが， 3 機 目の EDRS-D はアジア・オセアニア地区上空の静 止衛星への相乗りを予定しており, 我が国のスカ パーJSAT 社が Airbus 社に協力する予定である(13). 米国では, 衛星間光通信と光によるフィーダリン クの実験を併せて行う Laser Communications

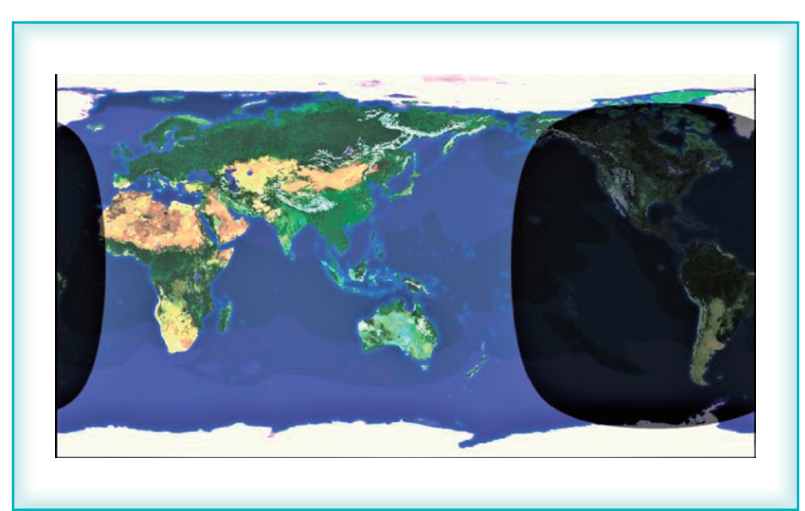

図 6 低軌道衛星が「こだま」と通信可能な範囲 
Relay Demonstration（LCRD）という光通信実験 ミッション ${ }^{(14)}$ が，2020 年（文献では 2019 年と あるが延期されている）に打上げ予定である。本 ミッションはマサチューセッツ工科大リンカーン研 (MIT-LL:Massachusetts Institute of Technology Lincoln Laboratory）が波長 $1.5 \mu \mathrm{m}$ 帯での光ファ イバ通信の技術を踏まえて, 永年研究開発を行って きた成果である，遅延線検波差動位相キーイング (DD-DPSK:Delay line Detection,Differential Phase Shift Keying) 等をNASA が採用したもの である。ユーザデータ伝送レート $1.24 \mathrm{Gbit} / \mathrm{s}$, 変 復調速度 $2.88 \mathrm{Gbit} / \mathrm{s}$ (符号化率 $1 / 2$ ) での光通信 実験を行う予定である。

また NASA は，ハワイの山頂や砂漠に光地上局 を置いて, 主に光で静止衛星から地上への伝送を実 現しょうとしている。ただし，Kaバンドによる フィーダリンクも次期 TDRS の実用段階では併用 する計画である。低軌道上の国際宇宙ステーション 間で通信実験を行う ILLUMA-T という計画も進ん でいる ${ }^{(15)}$.

筆者が属する JAXA は，2019 年度打上げを目指 した静止衛星である光データ中継衛星 (JDRS:Japanese Data Relay System) を開発中で ある ${ }^{(16),(17)}$. JDRS は, JAXA が開発中の LEO の 高分解能地球観測衛星である, ALOS-3, ALOS-4 (共に 2020 年度打上げ予定) から, ユーザ伝送レー ト $1.8 \mathrm{Gbit} / \mathrm{s}$ でのデー夕伝送を実証し、更に実用化 する予定である。JDRS の軌道上イメージを図 7 に 示す，衛星間光通信では, NASA と同様に $1.5 \mu \mathrm{m}$ 帯の DD-DPSK を使用する。一方，静止衛星から 地上へのフィーダリンクには，前述の EDRS と同 じく雲による影響を受けない Kaバンドを用いる.

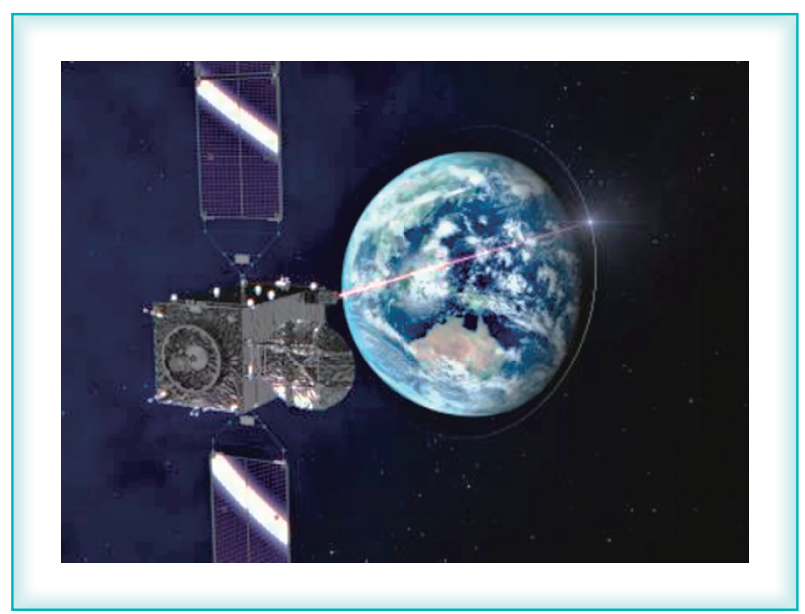

図 7 JDRS の軌道上イメージ (16)

我が国は世界的に見ても雲が多く ${ }^{(18)}$ ，EDRS と同 様にフィーダリンクには Ka バンドのみを用いてお り，フィーダリンクに関しては光に重きを置く NASA と異なっている.

また NICT は，2021 年度の打上げを予定する技 術試験衛星 (ETS:Engineering Test Satellite) 9 号機に搭載される, 静止衛星一地上間の光通信によ る超高速データ伝送（10Gbit/s 以上）の実証実験 のための宇宙光通信機器 HICALI (High Speed Communication with Advanced Laser Instrument）を開発中である ${ }^{(19),(20)}$.

表 1 に, これらのミッションの比較を示す.

なお中国では, 中国空間技術研究院 (CAST:China Academy of Space Technology) が開発した，光 通信装置を搭載した衛星「実践 13 号」が 2017 年 4 月に打ち上げられたと報道されている ${ }^{(21)}$ 。この 装置に関する公開情報は報道以外にはほとんど存在 せず，2015 年の宇宙データシステム諮問委員会 (CCSDS:Consultative Committee of Space Data

表 1 静止衛星を用いた光通信ミッションの比較

\begin{tabular}{|c|c|c|c|c|}
\hline & EDRS & LCRD & JDRS & HICALI \\
\hline 開発機関 & ESA/DLR & NASA/MIT LL & JAXA & NICT \\
\hline 打上げ & $\begin{array}{l}2016 \text { 年 } 1 \text { 月 } \\
\text { (EDRS-A) }\end{array}$ & 2020 年予定 & 2019 年度予定 & 2021 年度予定 \\
\hline 使用波長帯 & $1.06 \mu \mathrm{m}$ & $1.5 \mu \mathrm{m}$ 帯 & $1.5 \mu \mathrm{m}$ 帯 & $1.5 \mu \mathrm{m}$ 帯 \\
\hline $\begin{array}{l}\text { ユーザーデータ伝送 } \\
\text { 速度 (変復調速度) } \\
\text { (bit/s) }\end{array}$ & $\begin{array}{l}1.8 \mathrm{G} \\
\text { [双方向] } \\
(2.8 \mathrm{G})\end{array}$ & $\begin{array}{l}1.24 \mathrm{G} \\
{[\text { 双方向] }} \\
(2.88 \mathrm{G})\end{array}$ & $\begin{array}{l}1.8 \mathrm{G} \\
{[\mathrm{LEO} \text { から GEO] }} \\
(2.5 \mathrm{G})\end{array}$ & $\begin{array}{l}10 \mathrm{G} \\
\text { [双方向] } \\
(11.096 \mathrm{G})\end{array}$ \\
\hline 光通信の用途 & $\begin{array}{l}\text { 光データ中継システム } \\
\text { の衛星間光通信 }\end{array}$ & $\begin{array}{l}\text { 光フィーダリンク及び光 } \\
\text { データ中継システムの衛 } \\
\text { 星間光通信 }\end{array}$ & $\begin{array}{l}\text { 光データ中継システムの } \\
\text { 衛星間光通信 }\end{array}$ & 光フィーダリンク \\
\hline $\begin{array}{l}\text { データ中継のフィー } \\
\text { ダリンク }\end{array}$ & Ka バンド & $\begin{array}{l}\text { 光（実用時は Ka バンド } \\
\text { を併用する） }\end{array}$ & Ka バンド & $\begin{array}{l}\text { (フィーダリンク実験ミッ } \\
\text { ションのため適用外) }\end{array}$ \\
\hline
\end{tabular}


System） (22) の技術会合で彼らが報告した内容によ ると, 波長 $1.5 \mu \mathrm{m}$ 帯の位相変調といわゆるディジ タルコヒーレント復調を用いた宇宙光通信システム の開発を行っており，この内容で衛星が開発された と筆者は推定している。

\section{4 低軌道間・低軌道一地上間光通信}

最後に，低軌道（LEO）衛星－LEO 衛星の間, 及び LEO 衛星－光地上局間の宇宙光通信について 述べる。この分野は2. で述べたように，日本が LEO 一地上間の光通信を世界で初めて達成し，そ の後も DLR が低軌道衛星間通信を世界で初めて実 現するなど ${ }^{(4)}$ ，主に日欧の政府機関で開拓されて きた分野である。現在最も活発に研究開発が行われ ているこの分野は，月・惑星との光通信や静止衛星 を用いる光データ中継システムの研究開発が，現在 でも各国の宇宙機関 (NASA, ESA, DLR, JAXA) を中心に推進されていることとは対照的に，いわゆ る LEO コンステレーション（数十〜数千機の LEO 衛星群を用いた，グローバルな情報通信・インター ネット接続サービスを提供しようというチャレンジ ングな計画）と密接に結び付き，欧米の民間主導で 進んでいるものも多い. よって，それらの情報は積 極的に公開されているとは限らず，以下に紹介する 筆者が把握している情報が全てでも最新でもない可 能性が高いことを御容赦頂きたい. 例えば本論文を 執筆中に Space-X社は, Starlink という名の LEO コンステレーション衛星システムの第 1 回目打上 げとして，60 機の衛星を打ち上げたとのニュース が入ってきた ${ }^{(23),(24)}$ 。これは 60 機を 1 台のロケッ トで打ち上げるもので，最終的な衛星数は 10,000 機を超える. Space-X社は全くと言ってよいほど 学会では報告しないため, 米連邦通信委員会 (FCC:Federal Communication Commission) の申請内容以上のことは不明である。また，衛星間 通信に光通信を使うという情報もある ${ }^{(23)}$.

欧州においては，Leosat 社 ${ }^{(25)}$ が比較的小規模 な LEO コンステ構想を進めており，光通信装置の 開発を行っている。この構想の特徵は, LEO コン ステレーション全般が主張するところの「グローバ ルな情報通信・インターネット接続サービス」にお いて, 光ファイバの補完ではなく, 光ファイバ通信 よりも早いデータ伝送を, 物理的に保証しようとし ているところにある。すなわち, 即時性（低 Latency) の面で, 光ファイバ中の光速（約 20 万 $\mathrm{km} / \mathrm{s}$ ) よりも，真空・大気中での光速（約 30 万 $\mathrm{km} / \mathrm{s}$ ) が約 1.5 倍速いことを生かして, 例えばロ
ンドンーシンガポールといつた長距離データ伝送に おいて, LEO コンステレーションならば $60 \mathrm{~ms}$ 早 くデータ伝送できるとうたっている。この 60ms は, $\mathrm{ms}$ 単位でのコンピュータ取引を行っていると される現在の金融取引においては，利用者に圧倒的 な優位性を与えるとのことである。なお文献（26） は，高速金融取引関係者は，短波通信（今どき！) まで使って, 大西洋を越える距離なら光ファイバよ り時間的に早いという意味での高速通信を実現しよ うとしていることを紹介しており, Leosat 社の狙 いは間違ってはいないと思われる。

前項で述べた GEO の衛星は，1 機が質量 2〜4t, 開発費 100 億円以上，打上げに 1 回数十億円〜 百億円のコストを要する。高コストのため，10〜 15 年の長期運用すなわち長寿命・高信頼性が前提 となっている。一方, LEO コンステレーションで は，3〜 5 桁の数の衛星を同時期に運用する必要が ある. 総投資額としてどの計画でも数十億米ドルで あることから, 衛星を抜本的に小形・低コスト化 し，多数の衛星を同時に打ち上げることが必須と なっている。

この計画への採用を目指していると思われる研 究開発として, Thales 社は Optel- $\mu$ という小形光 通信装置を ESAの支援で開発しており，早ければ， 本論文が出版されるときには衛星に搭載の上，軌道 上で実証実験中の予定である ${ }^{(27)}$.

EDRS 用の光通信システム, 装置を開発し供給し ている独 Tesat 社も，この分野への参入を明言して おり，低コスト光通信装置や光地上局設備の開発を 行っている ${ }^{(28)}$. また, DLR の光通信研究グループ からのスピンオフ企業を前身に持つ Mynaric 社 ${ }^{(29)}$ も低コストの衛星搭載用光通信装置の開発を行うと ともに, 光地上局設備, 航空機用無線光通信装置の 製造販売を開始している。

ESA は，欧州の衛星コンステレーション計画を 後押しするためか, GEO/LEO 衛星技術の革新を目 指した, HydRON と名付けた研究開発プロジェク トを開始しており ${ }^{(30)}$ ，構想ではあるが，2025 年 ごろに GEOを 1 機, LEOを 1 機, それぞれ打ち 上げて軌道上実証を検討している。

米国においては，いわゆる“GAFA”の中で Google, Facebook が宇宙光通信に関する研究開 発を行っている。 Google は，大形気球を用いた基 地局サービスを開始しており ${ }^{(31)}$ ，この気球間を接 続する目的で, 光通信装置の研究開発を行っている (32) 。耐環境性要求が異なりそのまま宇宙で使える 技術ではないと思われるものの，その実績は宇宙光 


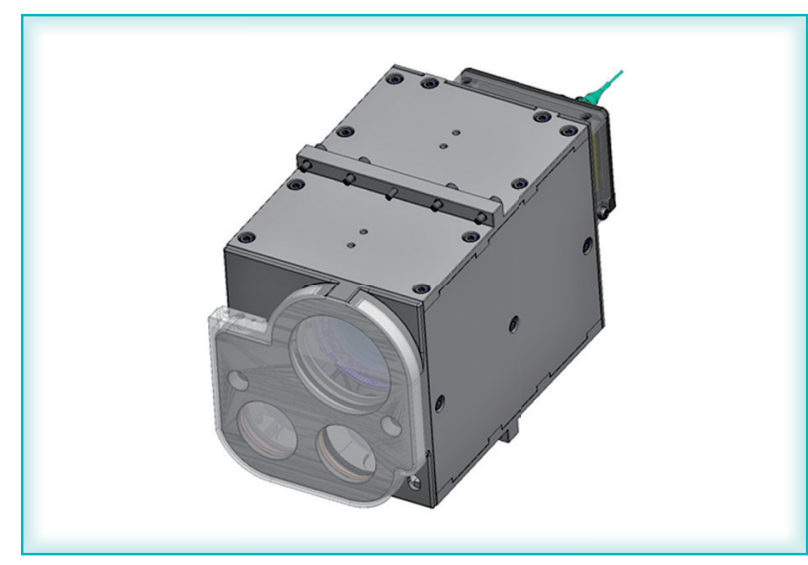

図 8 ソニーの光通信装置の外観 ${ }^{(36)}$

通信にも活用可能であろうと筆者は推定している. Facebook は，直接 ${ }^{(33)}$ 及び大学への資金提供 ${ }^{(34)}$ の双方の手段で, 研究開発を進めており, 学会でも 盛んに報告している。なお，Facebook Connection Lab の宇宙光通信に関する責任者は，数年前まで NASA JPL の宇宙光通信研究室長であった宇宙光 通信分野では著名な人物である。米国における人材 の移動のダイナミズムを表しているとともに, Facebook が宇宙（あるいは無線）光通信を用いた インターネットサービス網構築に本気であると世界 に表明した事件であった。

本項の最後に，我が国における本分野へのチャレ ンジとして, ソニーの研究開発 ${ }^{(35),(36)}$ を紹介する. ソニーを含めて現在では世界で 2 社しか保有しな くなった（ちなみに，もう1社はパナソニック）, $\mathrm{CD} / \mathrm{DVD} / \mathrm{BD}$ 読出し／書込みのコア技術である光 ピックアップ技術は, $\mu \mathrm{rad}$ オーダの極めて高い レーザ送信方向制御精度を有している。この技術を 光通信の指向制御に活用し，低コストの宇宙光通信 装置を実現しょうというチャレンジである。予定 (37) より遅れているが，本論文が揭載される頃には 国際宇宙ステーション（ISS）日本実験モジュール 「きぼう」船外部に，ソニーがJAXA と協力し開発 した光通信装置が取り付けられ, NICT と協力して 光地上局との光通信実験を行っているはずである. ソニーが開発した光通信装置の外観を図 8 に示す.

なお，宇宙光通信に関する概説（和文）はこれま でに文献（38）～(40) でも報告されており，関心 のある方は御一読頂きたい.

\section{宇宙光通信の技術動向と課題}

本章では，主に大容量通信技術に焦点を当てた宇 宙光通信の技術動向と課題の紹介を行う。また，宇宙

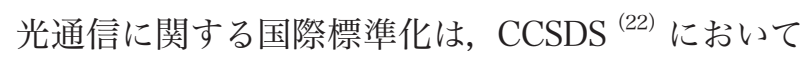

進められている. CCSDS の Optical Communication Working Group での最新の標準化活動状況の枠組み に沿って, 宇宙光通信での大容量伝送技術について まとめる。

\section{1 パルス位置変調方式とターボ符号の組合せ}

パルス位置変調 (PPM:Pulse Position Modulation) は, 距離 38 万 $\mathrm{km}$ の月探査機, 億 $\mathrm{km}$ 単位の惑星探 査機との超遠距離通信に用いることを想定して標準化 が進んでおり, High Photon Efficiency (HPE) と 呼称されている方式である。技術標準書案において 想定している最大通信レートは 500Mbit/s である. 電波の無線通信において, 1 シンボルで複数 bit の 情報を伝達するためには位相・振幅情報をシフトさ せた多值変調を用いている。光ファイバ通信では同 様に多值化が進みつつあるが，PPM は図 7 に示す ように一つの光のパルスがある場所によつて, 複数 bit の情報を表現するものである. 図 7 の例では, 一般的な Optical On Off Keying (O3K, IMDD 方 式別称）の Non Return to Zero（NRZ）方式で 4bit を送るためには平均して光のパルスが二つ（図 9 では台形で表現）必要なところが，PPM だと一 つで済む。検出器を 1 シンボルの検出限界で動作 させると，4bit を受信するため, PPM では半分の シンボルで済み, その分必要な受信電力が減少し, 復調部を高感度化することと同じ効果を得ることが 可能となる. 図 9 は 4 bit を 1 パルスで表現する PPM の例であるが，8bitを1 パルスで表現する PPM まで規格化されている.

HPE と呼ばれる通信方式は, PPM に, 高い誤り 訂正能力を有する, SCCC (Serially Concatenated Convolutional Code, ターボ符号の一種）と, 超 伝導ナノワイヤによる光子検出器を組み合わせるこ とで, 1 光子 $/$ bit 前後の超高感度検出を行うもので ある。

本方式の技術勧告ドラフト版は，既に CCSDS の Web サイト ${ }^{(41)}$ からダウンロード可能である。ま た, 本方式は 2020 年代後半から開始される, 国際協 力による有人月探査計画においても, 月一地球の高 速デー夕伝送回線（上り=地球から月 $=20 \mathrm{Mbit} / \mathrm{s}$, 下り $=$ 月から地球 $=500 \mathrm{Mbit} / \mathrm{s}$ ，暫定）に用いる ことが，CCSDS 技術会合にて議論されている。

\section{2 位相変調とホモダイン検波／遅延線検波の組合 せによる高速宇宙光通信システム}

既に 3.3 で述べた，ドイツが開発し ESA が採用 したBPSKとホモダイン検波の組合せ, 及び 


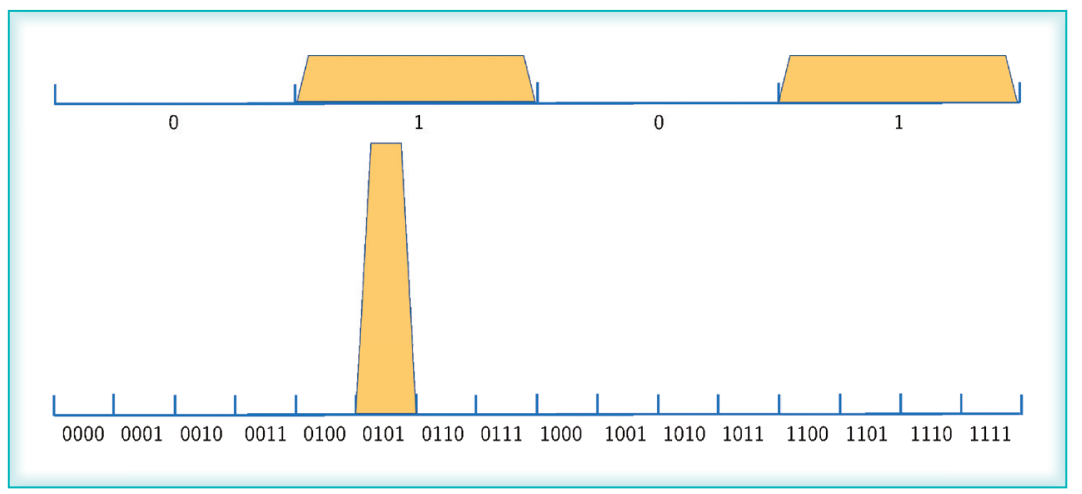

図 9 PPM 方式の概念

NASA/MIT-LL，JAXA が採用している DD-DPSK は，現在運用中あるいは開発中のシステムでは $2.5 \mathrm{Gbit} / \mathrm{s}$ 程度の通信速度であるが，波長多重化や いわゆるディジタルコヒーレント復調技術の採用 で，数十 Gbit/s への高速化が達成可能であると筆 者は考元, 研究開発を行っている ${ }^{(39),(40),(42) . ~ ま た, ~}$ CCSDS にて, 米 NASA/ 仏 CNES と日本 (JAXA, NICT) が協力して, 予備勧告案を作成している. 本システムの実現に向けた大きな技術課題は, 次の 2 点である.

\section{（1）10W 級光 HPA（High Power Amplifier）}

筆者らが検討している次期光データ中継システム では，まずューザデー夕伝送速度が JDRS の 8 倍 (14.4Gbit/s) 以上, 変復調速度 $20 \mathrm{Gbit} / \mathrm{s}$ 程度の高 速通信の実現を目指している ${ }^{(42)}$.この 20Gbit/s は, 一例として 4 值位相変調 (QPSK:Quadrature Phase Shift Keying) $5 \mathrm{Gbit} / \mathrm{s} \times 4$ 波長多重を想定し ている. 5Gbit/sQPSK 伝送は，前述の CCSDS 予 備勧告案の送信クロックレート $10 \mathrm{GHz}$ 若しくは $2.5 \mathrm{GHz}$ に沿ったものである.

復調方式にいわゆるディジタルコヒーレント方 式を用いれば，受信側の感度をJDRS の遅延線検波 から 2 倍以上改善できる。この場合, 上記の高速 化の実現のためには, 併せて光 HPAとして, JDRS の送信出力である 2〜3W ${ }^{(17)}$ から，10 Wへ の高出力化が必要になると筆者らは判断している.

これまでに宇宙で使用された実績のある通信用 ( $\mathrm{GHz}$ の高速変調光を増幅する) 光 HPA は, 例え ば文献（9）で述べられている LADEE で用いられて いる，シングルクラッドのエルビウム添加ファイバ (EDF:Er-Doped Fiber) を用いた 500mWEDFA ${ }^{(43)}$ (EDF Amplifier) 止まりである. 高出力化の工夫と して, イッテルビウムを添加する (EYDF:Er-YbDoped Fiber), ダブルクラッド型を採用する等が あるが，これらを宇宙で使用したという報告はまだ
ない. NASA/JPL では, 惑星探査機搭載用の $6 \mathrm{~W}$ の EYDFA を地上で検証し ${ }^{(44)}$, 実験室レベルでは 51Wの EYDFAを試作している ${ }^{(45)}$ 。なお, JDRS 用の HPA は，開発段階である.

光 HPA に関するもう一つの課題は, 衛星搭載機 器は宇宙線の影響を受け, かつ特に GEO は放射線 量が高いため, EDF/EYDF が放射線劣化により透 過損が大きく増加し光 HPA の出力が低下すること である．現在のところ，10W 級の光 HPA を実現可

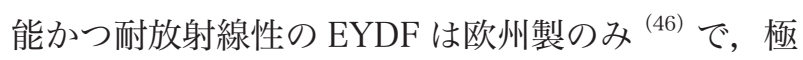
めて高価格の上に経験的に供給が安定的とは言い難 い、そこで筆者のグループは，より性能の良い宇宙 用 EYDF の研究開発を行っているところである ${ }^{(47)}$.

（2）ディジタルコヒーレント復調用の高速大容量 DSP 若しくはFPGA

JDRS，NASA の LCRD では，3. で述べたよう に復調技術として地上の光ファイバ通信では既にそ の使命を終えようとしているDD-DPSKを使用し ている。筆者らは 2020 年代後半の $20 \mathrm{Gbit} / \mathrm{s}$ 化, あるいは更なる高速化に向けては, いわゆるディジ タルコヒーレント方式の復調復号の適用を考えてい る。ディジタルコヒーレント方式は，上く知られた とおり局発光と混合した信号光を電気信号に変換し た後の処理をディジタル的に行う復調方式である。 変復調, 特に復調・復号で必要となる高速大容量 Digital Signal Processor (DSP), Analogue-toDigital Converter (ADC), Digital-to-Analogue Converter (DAC) 等の高速動作する ICでは, 宇 宙線, 特に重粒子線によるビット反転 (SEU:Single Event Upset）等に代表される, シングルイベント 効果 (SEE:Single Event Effect) による誤動作の 排除のため, SEE の影響を受けないディジタルデ バイス, 若しくは影響回避策の実現が必要である.

例えばディジタルコヒーレント技術を用いた 100Gbit/s のトランシーバを宇宙空間で用いた場 
合, ディジタルコヒーレントトランシーバの本体が 最先端の高集積 DSP であることから，特に処理が 複雑な復調復号部で SEE によるエラーを頻発する ことが予想される。

一方，放射線耐性のある宇宙機用の中央演算装置 (CPU:Central Processing Unit) /DSP は, 地上の 最先端品に比べて 10 年あるいはそれ以上前の性能 となっており，最先端のディジタル処理技術を宇宙 で使用するのは容易ではない. Statistic Random Access Memory（SRAM）型の高速大容量 Field Programable Gate Array（FPGA）を例にとると, 現在, 宇宙で使用可能と供給業者が保証しているも のでは，Xilinx 社の Virtex-5 ${ }^{(48)}$ が最も高速大容量 である。このVirtex-5においても，宇宙放射線に よる誤りの影響を低減するため, 内部への回路書込 み時にツールが自動的に三重多数決回路化（同時に 同じ処理を三つ走らせ，仮に一つ誤つても多数決決 定で正しい出力を得る）し書き込んでいる.Xilinx 社によると, 数年前から Ultrascale+の宇宙機搭載 化を進めているとのことであり，近い将来使える見 込みである。問題点は，一般的に高価な宇宙用部品 (クラス 1 と呼ばれる最もグレードの高いものだと 受注生産, 全数全工程記録等を行うため) の中で も，FPGA は著しく高価なことである。ちなみに, 宇宙用の Virtex-5 はポルシェが買える值段である.

なお，世界的にも雲が多い我が国にデー夕を下ろ すためには, 当面は光ではなく $\mathrm{RF}$ ( $\mathrm{Ka}$ バンド) による, 中継衛星から地上との高速回線が併せて必 要と考えている（図 5)。高速な DSP,FPGA は高速 Ka バンド通信に括いても重要な技術課題であり, Ka バンドのフィーダリンクの高速化についても JAXA にて研究開発を行っている ${ }^{(49)}$.

\section{3 光ファイバ通信システム技術をそのまま使用す る宇宙光通信構想}

前項の技術は，地上の技術を宇宙用の耐放射線を 有し, 高い品質保証を行った部品（いわゆる宇宙用 部品）を用いた装置を宇宙専用に開発しようというも のである，容易に想像がつくと思うが，地上用装置 に比べて著しく高価になりまた調達期間も長くなる。

近年, Facebook/MIT と, NASA/MIT-LL が別々 に, 光ファイバ通信用の $100 \mathrm{Gbit} / \mathrm{s}$, 若しくは 200Gbit/s トランシーバモジュールを高度 400〜 $1,000 \mathrm{~km}$ の低軌道衛星に搭載し, 低軌道衛星から 地上へ 100〜200Gbit/s の光通信を行うことを計画 している ${ }^{(34),(50)}$.この場合でも, 放射線が比較的 弱い低軌道において, かつ送信にのみ使用し，また
文献 (49) では地上での復調復号後, デー夕の大 きな誤りや欠落があれば再送制御を行う考え方を 取っている. 光デー夕中継衛星の静止軌道は, 放射 線の強いバンアレン帯 (Van Allen Belt) の外側で あり, 低軌道に比べてざっと 10 倍の放射線を浴び る。特に SEEを起こす重粒子が多く, 現状では地 上用の光ファイバ通信用のトランシーバモジュール が静止軌道で復調復号に使えるかどうかの検討や検 証については世界的に未着手のままである.

一方，近年の論理回路の高集積化に伴い，地上の 情報通信システムでも，宇宙からの粒子線によるエ ラーが問題となりその対策が必要とされてい る ${ }^{(51)}$. 地上用のディジタルコヒーレントのトラン シーバを含む超高速通信システムの衛星搭載化も, あるいはこういった取組みと, 従来の宇宙での取組 みとの融合で実現するものかもしれない.

\section{結言}

宇宙光通信の特徵・歴史を概観し, 現在の研究開 発動向を, 特に大容量デー夕伝送の観点からまと めた。

最後に筆者の私見を述べる. 我が国では, 光ファ イバが離島にまで行き渡り, 山奥にでも行かない限 り携帯電話が使える環境にある。そのため, 宇宙通 信というと非常時のみお世話になるという認識に なってしまうが，世界的には光ファイバの恩恵を受 けられない人々は「残り 30 億人 (Rest 3Billions)」 も存在している.

光ファイバ通信技術はすばらしい技術であり, 我々は日々その恩恵を受けている。 しかし光ファイ バはぜい弱なインフラであり, 本論文執筆中にも伊 豆諸島への光ファイバ海底ケーブルが故障し, 伊豆 諸島のインターネット・携帯サービス等が一時不通 になったとの報道があった ${ }^{(52)}$. 思い出せば，東日 本大震災の際には日本と世界を結ぶ海底ケーブルは 大損害を受け，幸運にも生き残ったケーブルがあっ たため世界との通信は保たれた ${ }^{(53)}$.

東日本大震災は未曾有の大災害とはい元, 被害地 域はその名のとおり東日本の特に太平洋岸であった ため光ファイバ海底ケーブルは全滅しなかった。し かし，災害ではなくいわゆる「有事」であれば，数 の限られたぜい弱な光ファイバ海底ケーブルは格好 の攻撃目標になり, 現状では我が国は細い衛星通信 回線しか使えなくなり, 通信回線不足により, 情報 的に大混乱になるであろう。

3. で紹介したいわゆる衛星コンステレーション 
計画は，欧米の民間による主導で進んでいるが，島 国である我が国こそ「いざ」というときのために， 切実に必要としていると筆者は考えている.

最後に，本論文を読んでいるであろう若い読者に お願いする．日常・国内の感覚で将来を考えるので はなく，非日常・グローバルに世界を俯瞰してある べき将来を想像し, 研究開発を進めて頂きたい.

\section{文献}

(1) A. Mody, E. Gonzalez, “An operator's view:The medium-term feasibility of an optical feeder link for VHTS," Proc. IEEE International Conference on Space Optical Systems and Applications (ICSOS)2017, pp.288-295,Nov. 2017.

(2) V. W. S. Chan, "Optical satellite networks," J. Lightwave Technol., vol.21, no.11,pp.28112827,Nov. 2003.

（3）荒木智宏，稲岡和也，田島成将，島田政明，鳩岡恭 志, 大澤右二 “ALOS-2 ミッションを支える高速デー 夕伝送システム（その1）衛星間通信サブシステム， 第 56 回宇宙科学技術連合講演会予稿集 1 K 11 , Oct.2012.

(4) Z. Sodnik, B. Furch, and H. Lutz, "Optical Intersatellite Communication," IEEE J. SELECTED TOPICS IN QUANTUM ELECTRONICS, vol. 16, no. 5, pp.10511057,May 2010.

(5) K. Araki, Y. Arimoto, M.Shikatani, M. Toyoda, M. Toyoshima, T. Takahashi, S. Kanda, and K. Shiratama, "Performance evaluation of laser communication equipment onboard the ETS-VI satellite," Proc. SPIE,vol. 2699,pp.52-59,March 1996.

(6) T. Jono, Y. Takayama, K. Shiratama, I. Mase, B. Demekenne, Z. Sodnik, A. Bird, M. Toyoshima, H. Kunimori, D. Giggenbach, N. Perlot, M. Knapek,and K. Araki, "Overview of the interorbit and orbit-to-ground laser communication demonstration by OICETS," Proc.SPIE vol.6457,645702,March 2007.

(7) S. -K. Liao, W.-Q. Cai, W.-Y. Liu, L. Zhang, Y. Li, J.-G. Ren, J. Yin, Q. Shen, Y. Cao, Z.-P. Li, F.-Z. Li, X.-W. Chen, L.-H .Sun, J.-J. Jia, J.-C. Wu,X.-J. Jiang, J.-F. Wang, Y.-M. Haung, Q. Wang, Y.-L. Zhou, L. Deng, T. Xi, L. Ma, T. Hu, Q. Zhang, Y.-A. Chen, N.-L. Liu, X.-B. Wang, Z.C. Zhu, C.-Y. Lu, R. Shu, C.-Z. Peng, J.-Y. Wang, and J.-W. Pan, "Satellite-to-ground quantum key distribution," Nature,vol.549,pp.4347,Sept.2017.

（8）さいとう・たか拀, “ゴルゴ 13 「剥がれた鋌金」, ビッグコミック,2001 年 12 月号,Dec.2001。(現在 入手可能な書籍は S P コミックス ゴルゴ 13114 巻, リイド社, 東京, 2006.)

(9) D. Cornwell, "NASA's optical communications program for 2015 and beyond," Proc. SPIE vol. 9354, 93540E,March 2015.

(10) A. Biswas, M. Srinivasan, R. Rogalin, S. Piazzolla, J. Liu, B. Schratz, A. Wong, E. Alerstam, M. Wright, W. T. Roberts, J. Kovalik,
G. Ortiz, A. Na-Nakornpanom, M. Shaw, C. Okino, K. Andrews, M. Peng, D. Orozco and W. Klipstein, "Status of NASA's deep space optical communication technology demonstration," Proc. IEEE International Conference on Space Optical Systems and Applications(ICSOS) 2017,pp.23-27.Nov.2017.

(11) https://www.nasa.gov/directorates/heo/scan/ services/networks/tdrs_main

(12) H. Hauschildt, S. Mezzasoma, H. L. Moeller, M. Witting and J. Herrmann, "European data relay system goes global” Proc. IEEE International Conference on Space Optical Systems and Applications (ICSOS) 2017, pp.15-18, Nov.2017.

(13) SJSAT 2019 年 2 月 4 日 プレスリリース「光データ 中継事業の共同展開に向けてエアバス社と覚書を締 結 」(2019) https://www.sptvjsat.com/load_pdf. php?pTb=t_news_\&pRi=1380\&pJe=1

(14) D. Cornwell, "NASA's optical communications program for 2017 and beyond,” Proc. IEEE International Conference on Space Optical Systems and Applications (ICSOS)2017, pp.1014,Nov.2017.

(15) T. Shih, O. Guldner, F. I. Khatri, J. W. Murnside, C. De Voe, W. Hubbard, S. Constantine, J. Torres and B. S. Robinson, "A modular, agile, scalable optical terminal architecture for space communications," Proc. IEEE International Conference on Space Optical Systems and Applications(ICSOS)2017, pp.213-217, Nov. 2017.

(16) Y. Sato, Y. Miyamoto, Y. Takano, S. Yamakawa and H. Kohata, "Current status of Japanese optical data relay system (JDRS),” Proc. IEEE International Conference on Space Optical $\mathrm{S}$ y s t e m s a n d A p p l c a t i o n s (ICSOS)2017,pp.250-252,Nov. 2017.

（17）山川史郎, “光データ中継衛星 宇宙利用拡大のため のインフラストラクチャ,” OPTRONICS,vol.38,no .446,pp.72-77, Feb.2019.

(18) https://earthobservatory.nasa.gov/images/85843/ cloudy-earth

(19) M. Toyoshima, T. Fuse, A. Carrasco-Casado, D. R. Kolev, H. Takenaka, Y. Munemasa, K. Suzuki, Y. Koyama, T. Kubo-oka, and H. Kunimori, "Research and development on a hybrid high throughput satellite with an optical feeder link Study of a link budget analysis" Proc. IEEE International Conference on Space Optical Systems and Applications(ICSOS)2017, ,pp.277282, Nov. 2017.

（20）久保岡俊宏，宗正 康，“技術試験衛星 9 号機にお ける光フィーダリンクシステムの開発と今後の展 望, ”OPTRONICS vol.38,no.446,pp.7882,Feb.2019.

(21) h t t p : / / w w w . c a s t. c n / I t e m / S h o w . asp? $\mathrm{m}=1 \& \mathrm{~d}=5725$ (in Chinese)

(22) http://stage.tksc.jaxa.jp/ccsds/index.html

(23) https://en.wikipedia.org/wiki/Starlink_(satellite_ constellation)\#Satellite_hardware

(24) https://spacenews.com/spacex-launches-60starlink-satellites-begins-constellation-buildout/

(25) http://leosat.com/

(26) D. Schneider, "WALL STREET TRIES SHORT 
WAVE RADIO,” IEEE spectr. Jul 2018, p.12, July 2018.

(27) https://www.dlr.de/kn/Portaldata/27/Resources/ dokumente/02_aktuelles/3-d_ROTH-OEI-OPTO_ OLEODL_Nov_2016_OPTEL-u.pdf

(28) http://www.tesat.de/en/laser

(29) https://mynaric.com/

(30) H. Hauschdit, "HydRON: High throughput optical network," Proc.Free-Space Laser Communication and Atmospheric Propagation XXXI, Proc.SPIE vol. 10910, 109100K,Feb./ March 2019.

(31) https://loon.com/

(32) B. Moision, B. Erkmen, E.Keyes, T. Belt, O. Bowen, D. Brinkley, P. Csonka, M. Eglington, A. Kazmierski, N.-h. Kim, J. Moody, T. Tu, and W. Vermeer , "Demonstration of free-space optical communication for long-range data links between balloons on Project Loon, " Proc.FreeSpace Laser Communication and Atmospheric Propagation XXIX, Proc. SPIE vol.10096, $100960 Z$, March 2017.

(33) H. Hematti, "Lower frequency bands emerging as valid alternatives to free-space lasercom in terrestrial, aerial, and satellite links," Proc.FreeSpace Laser Communication and Atmospheric Propagation XXXI, Proc. SPIE vol. 10910 , 1091013, March 2019.

(34) R. J. Aniceto, "Heavy Ion radiation assessment of a 100G/200G commercial optical coherent DSP ASIC," Proc. Free-Space Laser Communication and Atmospheric Propagation XXXI, Proc. vol.10910, SPIE 1091011, March 2019.

(35) K. Iwamoto, Tomohiro Araki, Yuta Kobayashi, Hirotaka Sawada, Taiji Ito, Takeshi Sano, Yasuhiro Takeshita, Shinji Ota, Mituhiro Ueno, Kei-ichi Shibata, Takashi Nakao, and Hiromitsu Komatsu, "Experimental verifications on small optical inter-satellite communication system for small and micro satellites," Proc. IEEE International Conference on Space Optical Systems and Applications (ICSOS)2017, pp.59-62 Nov. 2017.

（36）岩本匡平，“光ディスク技術を用いた小型宇宙光通 信モジュールの研究開発, ” OPTRONICS,vol.38,no.446,pp.94-97,Feb.2019.

(37) http://www.jaxa.jp/press/2018/02/20180208_ i-seep_j.html

（38）豊嶋守生，“特集光技術 $\times$ 宇宙通信 総論，” OPTRONICS,vol.38, no.446,pp.66-71,Feb.2019.

(39) 荒木智宏, 小林雄太, “宇宙光通信の最新動向と JAXA における研究開発, ”信学技報,WBS201647,Oct.2016.

（40）荒木智宏，“宇宙光通信の現状，将来と技術課題, ” 信学技報, OCS2018-22, Aug. 2018 .

(41) https://public.ccsds.org/review/default.aspx

(42) T. Araki, "A study of the future optical data relay system; requirements, problems and solution," Proc. IEEE International Conference on Space Optical Systems and Applications(ICSOS)2017, pp.209-212. Nov. 2017.

(43) F. Hakimi, E. S. Kintzer,and R. S. Bondurant, "High-power single-polarization EDFA with wavelength-multiplexed pumps," CWKl CLEO' 98 , May 1998. に基づくものと NASA から聞いて いる.

(44) S. Gupta,D. Engin, D. Packowicz, J.-L. Fouron, J. Lander, X. Dang, S. Litvinovich, T. Chuang, K. Puffenberger, F. Kimpel, and R. Utano, "Development, testing and initial space qualification of $1.5-\mu \mathrm{m}$, high-power $(6 \mathrm{~W})$, pulseposition-modulated(PPM) fiber laser transmitter for deep-space laser communication,” Proc. Free-Space Laser Communication and Atmospheric Propagation XXVIII, Proc.SPIE vol.9723, 97390V, March 2016.

(45) D. Engin, J. Rudd, ,"51W, 1.5um, 7 WDM (25nm) channels PPM downlink Tx and 500W, lum, uplink PPM Tx for deep space lasercom,” Proc. Free-Space Laser Communication and Atmospheric Propagation XXXI, Proc.SPIE vol. 10910, 109100L, Mar. 2019.

(46) https://photonics.ixblue.com/store/lasersamplifiers-fibers/rad-hard-space-grade-dopedfibers

(47) Y. Kobayashi, E. H. Sekiya, K. Saito, R. Nishimura, K. Ichii, and T. Araki , "Effects of ge co-doping on p-related radiation-induced absorption in Er/ Yb-Doped optical fibers for space application," IEEE J.Lightwave Technol.,vol.36, issuel3,pp.2723-2729, March 2018.

(48) https://japan.xilinx.com/support/documentation/ data_sheets/ds 192_V5QV_Device_Overview.pdf

(49) C.Kato, Mitsuhiro Nakadai and Masanobu Yajima, "Performance evaluation of Ka-band telecommunication subsystem for earth observation satellites," Proc. 23rd Ka and Broadband Communications Conference, ka19-3. Oct. 2017.

(50) B. S. Robinson, "TeraByte infraRed delivery (TBIRD): a demonstration of large-volume directto-earth data transfer from low-earth orbit," Proc. SPIE Free-Space Laser Communication and Atmospheric Propagation XXX, vol. 10534, 105240V,March 2018.

（51）岩下秀徳，“宇宙線による通信装置のソフトエラー への取組と国際標準化活動,”ITUジャーナ ル ,vol.47,no.1,pp.37-49, Jan.2017.

(52) https://www.ntt-east.co.jp/tokyo/info/ detail/1258503 2608.html

(53) https://www.kddi.com/corporate/news release/201 1/0408/pdf/besshi2.pdf

(2019 年 5 月 28 日受付, 7 月 16 日再受付)

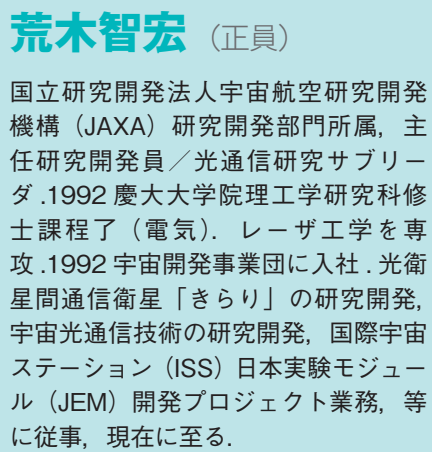

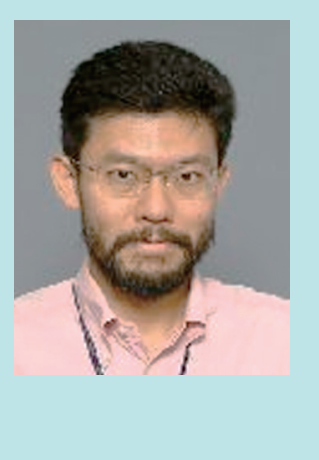

